\title{
Traditional and Current Knowledge on the Utilization of Mahua (Madhuca latifolia L.) Flowers by the Santhal Tribe in Similipal Biosphere Reserve, Odisha, India
}

\author{
S. Behera ${ }^{1}$, R. C. Ray ${ }^{2 *}$, M. R. Swain ${ }^{3}$, R. C. Mohanty ${ }^{1}$ and A. K. \\ Biswal $^{4}$
}

${ }^{1}$ Department of Botany, Utkal University, Vanivihar, Bhubaneswar -751004, Orissa, India,

${ }^{2}$ Microbiology Laboratory, ICAR-Central Tuber Crops Research Institute (Regional

Centre), Bhubaneswar-751019, Orissa, India, ${ }^{3}$ Department of Biotechnology,

College of Engineering and Technology, Bhubaneswar, ${ }^{4}$ Department of Botany,

North Orissa University, Takatpur, Baripada, Orissa

ABSTRACT

Mahua (Madhuca latifolia L.) (also called as mahua) is a tree commonly found in mixed deciduous forests of Asian and Australian Continents, often growing on rocky and sandy soils. The various parts of this tree serve as food, feed, and medicine, thus form a part and parcel in the sustainability of livelihood of the tribal people. A study was conducted in 2009 among the people of Santhal tribe in Odisha, India to get information (traditional and current) on the uses of this tree species, particularly on its edible flowers. The study area concentrated in and around the deep forest pockets of Chandbill village of Bangiriposi Block on the northern border of the Similipal Biosphere Reserve, Odisha. This tree species is found to substantially contribute to all sectors of tribal economy like food (flowers), beverage (flowers), and medicine (flowers, seeds and bark). Mahua flowers are fermented in to a distilled alcoholic beverage (country liquor, locally called "mahuli") in household and commercial scale. Mabuli, having an alcohol percentage of $30-40 \%$, is used as a supplement to rice as staple diet in their food habit.

Key words: Alcoholic beverages, Mahua, Traditional knowledge, Tribal people.

\section{INTRODUCTION}

Madhuca latifolia L. is an Indian tropical tree (Fig. 1a) found largely in the Central and North Indian plains and forests (Bhagmol and Joshi, 2002). It is abundant in mixed deciduous forests along with sal (Shorea robusta L.) and teak (Dalbergia sissoo L.) often growing on rocky and sandy soil. It is a fast growing tree that grows to approximately 20 meters in height and belongs to the family Sapotaceae (Awasthi et al., 1975).

Mahua trees are distributed from India to other Asian countries like Pakistan, The Philippines, Sri Lanka to Australia. In India, it is found in the states like Bihar, 
Jharkhand, Orissa, West Bengal, Madhya Pradesh, Kerala, Gujarat, Chhatisgarh, Uttaranchal, Maharastra and Sikkim (Awasthi et al., 1975). The annual production of mahua flowers in India was about $45000 \mathrm{M}$ tones (Behera et al., 2010a) from 2003-2004 and 2004-2005 (Swain et al., 2007).

Mahua tree is known to serve as a part and parcel in the sustainability of the Indian tribal people (Behera et al., 2010b). Agriculture is the main occupation of these people but the forest and its products play an important role to meet their multifarious requirement such as food, beverage, medicine, etc. This tree species has been domesticated in India and Pakistan for its uses as food (flower), feed (leaves and flower), wood (timber), and beverage (flower) locally called 'mabuli'. Besides, the seeds and bark of the tree have manifold uses as insect repellant, nutritional tonic, stimulant, and remedial measures for snakebites, bronchitis, and fish poison (Joshi, 2001). The corolla of mahua flowers is edible and is very rich in fermentable sugars (glucose and maltose) (The Wealth of India, 1962). The tribal people prepare a country liquor, mabuli, from these by fermentation (Bhagmol and Joshi, 2002); the liquor is used as a supplement to rice as staple diet. It can also serve as an alternate to sugarcane/starchy crops (i.e., maize and cassava) for bio-ethanol production (Swain et al., 2007; Behera et al., 2010a, b). However, there is no systematic/scientific study on how mahua flowers are collected; the same is true with its market supply chain, storage system and traditional uses into food, feed and alcoholic beverage. Therefore the present study aims to gather information on traditional as well as current uses of mahua flowers, especially on storage and methods of preparation for food, beverage, and other purposes. Traditional knowledge, is knowledge, know-how, skills and practices that are developed, sustained and passed on from generation to generation within a community, often forming part of its cultural or spiritual identity. Current knowledge is the knowledge that has been developed and practiced as a result of scientific and engineering research.

\section{MATERIALS AND METHODS}

\section{The Study Area}

The study area concentrated in and around the deep forest pockets of Chandbill tribal villages of Bangiriposi Block which is situated in the bank of Budhabalanga river passing through Similipal Biosphere Reserve (210 28/ to 220 08/ N latitude and 860 04/ to 860 37/ E longitude) located in part, in Mayurbhanj districts of Odisha, India (Fig. 1). Similipal range shows a diversified vegetation pattern i.e., from tropical deciduous to a virgin semi-ever green forest, which expresses the climatic climax type of vegetation (Braham et al., 1990).The region is very mountainous and complex mosaic of vegetation types as well as a high proportion of plant species. The soil of all the forest sites is reddish in color and loam to sandy loam in texture. The soil is slightly acidic in nature with $\mathrm{pH}$ ranging from 5.23 to 6.52 and average monthly soil moisture content varies from 18.13 to $40.25 \%$ (Mishra et al., 2006). Chandbill has been selected in this study due to the following points:

I. The village is situated in the vicinity of the Similipal forest which harbors rich bio-diversity. 
II. The village is chiefly inhabited by the Santhal tribes.

III. The dependency of the inhabitants upon the plants resources is high.

IV. The residents showed a deep knowledge and interest in mahua plants

Chandbill has a substantial number of elders, who are generally repositories of extensive mahua tree knowledge. Most importantly, Chandbill residents welcomed the opportunity to record the distribution of mahua tree and local use of the plant parts. The village had a population nearly 500 people belonging to "Santhal" community. The number of residents actually present in the village is variable at any time.

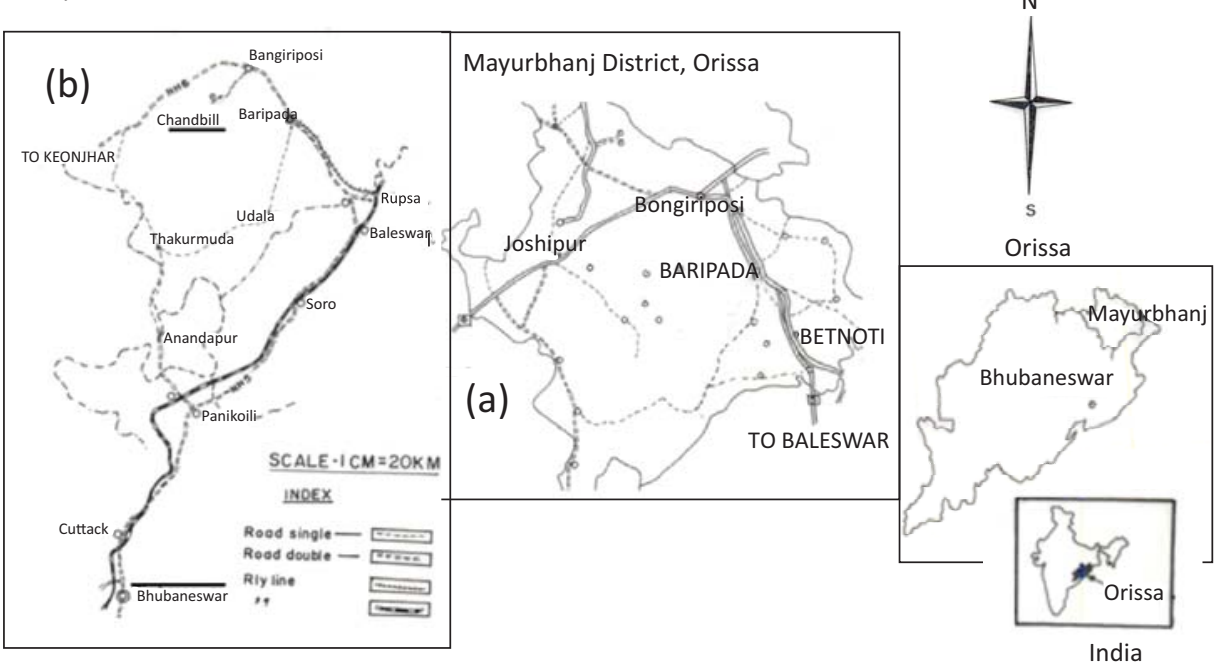

Figure 1. Location map of study area (a) Mayurbhanj District (b) Road and railway map from Bhubaneswar to Chandbil village, (Bangirposi, Dist. Mayurbhanj, Orissa, India).

\section{Methodology of Study}

Field research in Chandbill village was carried out in two field seasons for a total period of four months (February-March 2009 and May-June 2009). We initially visited the tribal area where they were utilizing the natural resources. During this field work, it was found that all tribal people were living under thatched roofs (Fig. 3b). During this time we became acquainted with the distribution of mahua species among the other plants. Botanical specimens like plant leaf, twig, and flower were collected with the help of the tribal people.

In total, 100 (56 men and 44 women, respectively) tribal people of different age groups (the youngest was 15 and oldest one 75 years old) in Chandbill village were formally interviewed for this study, on repeated basis. Participants were interviewed individually and in community gatherings. The questionaire focused on the uses of mahua flowers and seeds, and the categories were: "food", "feed", "medicine", "beverage" and "others". The questionnaire was administered in their languages by a person who helped us in our study. Different places were visited in the above mentioned village to observe and document the method of collection of 
mahua flowers, transportation and storage system, and uses.

Other uses of mahua flowers and seeds such as mabuli (liquor) production in commercial scale, some uses as food and feed, bio-diesel from seeds, bio-ethanol from flowers were obtained from secondary sources such as published work, website, etc.

\section{RESULTS AND DISCUSSION}

\section{Collection, Transport and Storage of Mabua Flowers}

\section{Collection}

The local tribal population irrespective of caste and class are involved in collection, drying and sale of Mahua flowers which provide an income source for them. They collect the flowers from private and forest lands during the month of March to April, the flowering season. The flowers are normally collected early in the morning by hand picking from the forest floor, which is sometimes bushy and inaccessible (Fig. 2a). Generally women and children are involved in collecting mahua flowers.

\section{Transport}

After collection, the flowers are packed in baskets, bags, and in gunny bags. The collected flowers are transported through a bicycle (Fig. 2b) and carts (Fig. 2c) to their homes. These flowers are either used for home consumption or sold in the market (Fig. 2d).

\section{Marketing}

The lack of sufficient storage space and need for money force tribal people to sell a large part of their collections of mahua flowers. Usually they sell the mahua flowers to middlemen in their local market (Fig. 2d).

\section{Storage}

The flowers after transportation are usually dried in sunlight $\left(\approx 40\right.$ to $\left.43^{\circ} \mathrm{C}\right)$ for 5 to 7 days. The dried flowers are packed in gunny bags (Fig 3c) and stored in dark ventilated rooms (Fig 3d). Mahua has a hygroscopic tendency and gathers moisture, especially during the monsoon, when moisture percolates from earthen floors and roofs. Almost $30 \%$ of all the mahua flowers collected from the forests are spoiled either by insects or microbes due to lack of proper storage facilities.

\section{Traditional uses of the Mabuaflowers}

\section{Food}

The most edible part of the mahua plant is the flower (Fig. 3e). The flowers are rich in sugar such as sucrose, glucose, fructose, and traces of maltose, arabinose, and rhamnose (Patel and Naik, 2010). In very fresh condition, the sugar content varies from $13-15 \%$, but in dried condition it increases up to $30-45 \%$ (Swain et al., 2007). Due to high percentage of sugar in flowers, these are used by the tribal people for admixing them with cereals i.e., rice, ragi, etc for preparing the following food items. 

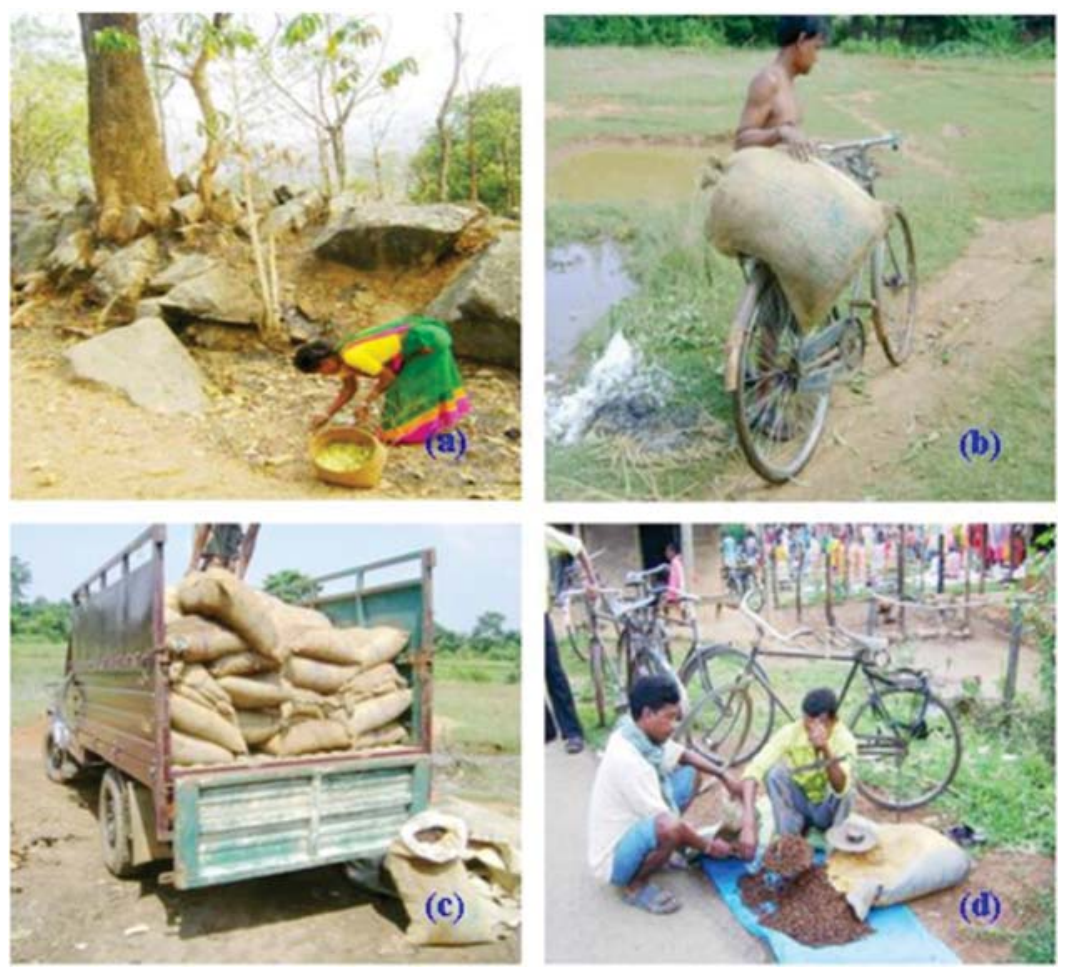

Figure 2. Collection, transportation, and selling of mahua flowers (a) Collection of mahua flowers from the ground by hand picking (b) Transportation of mahua flowers through bicycle (c) Transportation of mahua flowers through cart (d) Selling of mahua flowers in the tribal local market

\section{Cake}

Generally 250 gm mahua flowers and 500 gm rice are separately soaked in water for $1 \mathrm{~h}$. Then, both are mixed and grinded. The paste obtained from grinding is covered with the salleaves from both sides and burned with fire to make the cake (Fig. 3f). Other cereals such as ragi (Eleusine coracana L.), jowar (Sorghum vulgare L.), and root crops such as sweet potato (Ipomoea batatas L.) sometimes serve as substitute to rice.

\section{Beverage}

Mahua flowers are the most important raw material for production of alcohol and alcoholic beverages. An average yield of 90 gallons of $95 \%$ alcohol is reported from one ton of dried flowers (The Wealth of India, 1962). However, the use of mahua flowers for alcohol production is likely to continue in localities where they are available at low cost and where alcohol is intended for use as potable spirits.

\section{Small scaleproduction}

On this survey, it was observed that tribal people ferment mahua flowers openly in their locality, and fermented mahua flowers are distilled for production of "mabul". Usually, the flowers are thoroughly washed in water and submerged in plastic drums or tanks for a period of 4 days with the addition of 'starter culture', locally called as "bakhar (syn. 'ranu')", prepared from medicinal plants and cereals) (Fig. 3g). 

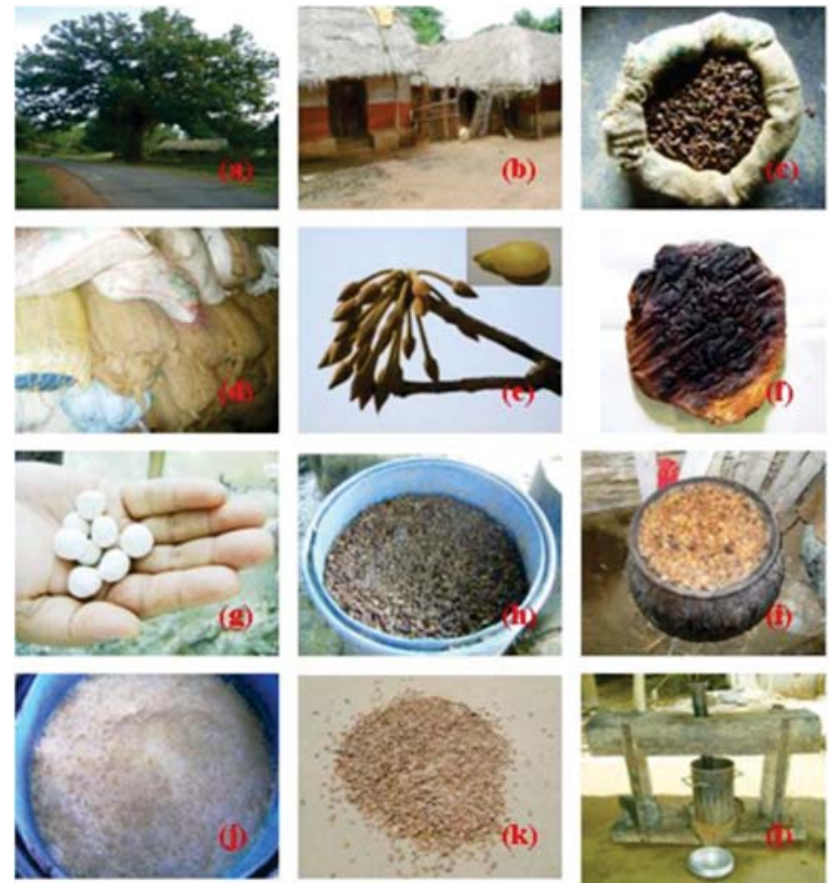

Figure 3. (a) Mahua tree (b) Tribal homes in Chandbill village, Bangirposi (c) Mahua flowers in gunny bag (d) Storage flower in gunny bags (e) Mahua bud and flower (insert) (f) Mahua cake (g) Bakhara (traditional additives prepared from medicinal plants and cereals) to enhance mahua Fermentation (h) Large scale mahua fermentation in plastic drum (i) Small scale mahua fermentation in earthen pot (j) Fruthing in fermentation batch (k) Mahua seed drying under sunlight (l) Oil extracting unit in Chandbill village, generally used for extraction of mahua oil from mahua seeds.

\section{Bakhar}

Bakhar or ranu (Fig. 3g) is prepared as follows. Raw rice grounded to powder is used as the base material. To it, roots and barks of the selected plants (Table 1) having medicinal properties such as Clerodendrum serratum, Dipteracanthus suffruticosus, Holarrbena pubescens, Madhuca indica, Smilax macrophylla, Woodfordia fruticosa, Xantolis tomentosa, Rauvolfia serpentine, Orthosiphon rubicundus are added as dry powder (Sharma and Biswal, 2010). About 5-10 pieces of previously preserved bakhar tablets are powdered and added to this mixture. The bakhar tablets contain fermenting microorganisms such as Saccharomyces cerevisiae and $S$. pombe in dried form (Sharma and Biswal, 2010). A little amount of water is added to the whole mash to make the dough. The dough is smoothened to rounded tablets, spread on straw bed in layer after layer, and dried under sun for about 2 days.

Generally, $10 \mathrm{~kg}$ of mahua flowers are mixed with $300 \mathrm{~g}$ bakhara and 32 liters of water. In another method $4 \mathrm{~kg}$ of mahua flowers is mixed with $6 \mathrm{~kg}$ molasses, 300 gm bakhara and 32 liter of water. Fermentation is carried out in plastic drums (Fig. $3 \mathrm{~h}$ ) or in earthen pots (Fig. 3i). The fermentation time is varied depending on seasonal temperature. In winter, fermentation time ranges from 6-7 days and in summer it is reduced to 3 - 4 days. Fermentation process is confirmed by observing frothing in fermentation batch (Fig. 3j). 
Fermented mahua flower mass is distilled in a metallic (aluminum) container by keeping another earthen pot on the top of the first container reversely. The joints of two vessels are sealed by using sticky pond mud. A metallic pipe is connected to the upper earthen vessel which passes through water and opens to a collecting vessel. The lower metallic container containing fermented mahua flower mass is heated at low temperature with wood fire. Finally, the steam is condensed in metallic pipe and collected in the collecting vessel. The traditional distillation process is described graphically in the Figure 4. The alcohol (ethanol) concentration in the distilleries varies between from $30-40 \%$. The distillate produced from only mahua flowers $(10 \mathrm{~kg})$ and mahua + molasses $(4 \mathrm{~kg}$ mahua flowers and $6 \mathrm{~kg}$ molasses) are 6.5 and 9 liter per batch, respectively. The distillate is diluted to approximately 10-15\% alcohol (ethanol) and consumed as "country liquor".

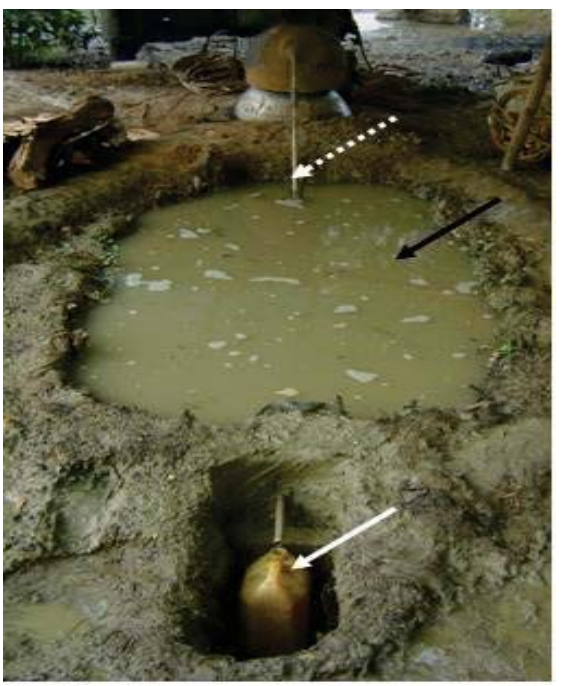

Figure 4. Small scale traditional mahuli distillation process from fermented mahua flower. Dotted white arrow: Metallic pipe connected to the upper vessel, Black arrow: Mud water, through which metallic pipe passes and it helps in condensing vapors to liquid, White arrow: Condensed Mahuli Collecting vessel.

\section{Commercial Scale Production}

Some private organizations are producing "mahuli" in commercial scale taking legal permission from the Orissa State Government (Fig. 5). They usually use larger plastic drums or jar for fermenting mahua flowers. After fermentation the distillation process is almost same as described in the small scale process. In this process $50 \mathrm{~kg}$ mahua flowers and $50 \mathrm{~kg}$ molasses fermented together. The final distillate comes around 80 liter/batch. For better fermentation Asana leaf extract or Poi (Basella rubra L.) plant extract is used at approximately at $1 \%$ during fermentation. The ethanol concentration varies between $35-40 \%$. Finally, distillate is diluted to various concentrations ranging from 10 to $18 \%$ alcohol (ethanol) depending on market demand. 
Table 1. Phytotherapeutic uses of plants used in preparation of bakhar.

\begin{tabular}{|c|c|c|c|c|c|}
\hline $\begin{array}{l}\mathrm{Si} \\
\mathrm{No}\end{array}$ & Name of the Plant & Local Name & Family & $\begin{array}{l}\text { Parts } \\
\text { used }\end{array}$ & $\begin{array}{c}\text { Medicinal } \\
\text { uses/properties }\end{array}$ \\
\hline 1 & Asparagus racemosus Willd & Kader & Liliaceae & Roots & $\begin{array}{l}\text { Roots used curing } \\
\text { fever, nutritive tonic, }\end{array}$ \\
\hline 2 & Cissampelos pareira $\mathrm{L}$ & Andia kidula & Menispermaceae & Roots & $\begin{array}{lll}\text { Roots used } & \text { to } \\
\text { increase milk } & \text { in } \\
\text { lactating mother, } & \end{array}$ \\
\hline 3 & $\begin{array}{l}\text { Clerodendrum serratum } \\
\text { (L) Moon, Cat. Pl }\end{array}$ & Saram lutur & Verbenaceaer & Roots & $\begin{array}{l}\text { Roots used in } \\
\text { rheumatism }\end{array}$ \\
\hline 4 & $\begin{array}{l}\text { Dipteracanthus } \\
\text { suffruticosus (Roxb.) Voigt }\end{array}$ & Ranuran & Acanthaceae & Roots & $\begin{array}{l}\text { Roots used in renal } \\
\text { problems }\end{array}$ \\
\hline 5 & Elephantopus scaber L. & Hadem ran & Asteraceae & Roots & $\begin{array}{l}\text { Roots used in } \\
\text { diarrhoea, dysentery }\end{array}$ \\
\hline 6 & Gardenia gummifera L.f. & Bhurlu & Rubiaceae & $\begin{array}{l}\text { Young } \\
\text { shoot }\end{array}$ & $\begin{array}{ll}\text { Gums of young } \\
\text { shoot used in } \\
\text { nervous } & \text { disorder of } \\
\text { children } & \end{array}$ \\
\hline 7 & $\begin{array}{l}\text { Holarrhena pubescens } \\
\text { (Buch Ham) Wall ex. G. } \\
\text { Don }\end{array}$ & Hat & Apocyanaceae & Bark & $\begin{array}{l}\text { Bark used in } \\
\text { amoebic dysentery } \\
\text { and diarrhea }\end{array}$ \\
\hline 8 & $\begin{array}{l}\text { Homalium nepalense Benth } \\
\text { J Linn. }\end{array}$ & Danmari & Flacourtiaceae & Bark & $\begin{array}{l}\text { Bark juice is used to } \\
\text { cure colic }\end{array}$ \\
\hline 9 & $\begin{array}{l}\text { Lygodium flexuosum (Linn.) } \\
\text { Sw }\end{array}$ & $\begin{array}{l}\text { Nanjam } \\
\text { rehed, Aliz } \\
\text { tukah }\end{array}$ & Lygodiaceae & Roots & $\begin{array}{l}\text { Fresh roots used in } \\
\text { eczema }\end{array}$ \\
\hline 10 & Madhuca indica Gmel. & Matkam & Sapotaceae & $\begin{array}{l}\text { Seeds, } \\
\text { Leaves } \\
\& \text { Bark }\end{array}$ & $\begin{array}{l}\text { Mahua oil obtained } \\
\text { from seeds is used in } \\
\text { rheumatism; leaves } \\
\text { and bark used in } \\
\text { diabetes }\end{array}$ \\
\hline 11 & $\begin{array}{l}\text { Ochna obtusata DC. Var. } \\
\text { pumila (Buch Ham. Ex DC) } \\
\text { Kanis }\end{array}$ & Ot champa & Ochnaceae & Roots & $\begin{array}{l}\text { Roots used as } \\
\text { antidote in snake } \\
\text { bite }\end{array}$ \\
\hline 12 & $\begin{array}{l}\text { Orthosiphon rubicundus (D. } \\
\text { Don) Benth }\end{array}$ & $\begin{array}{l}\text { Khara ranu } \\
\text { ran }\end{array}$ & Lamiaceae & $\begin{array}{l}\text { Roots } \\
\text { tuber }\end{array}$ & $\begin{array}{l}\text { Roots tubers used to } \\
\text { cure colic }\end{array}$ \\
\hline 13 & $\begin{array}{l}\text { Polygala crotalarioides } \\
\text { Buch Ham ex DC }\end{array}$ & Lilkathi & Polygalaceae & Bark & Used for cough \\
\hline 14 & $\begin{array}{l}\text { Phoenix acaulis } \\
\text { Buch. Ham ex Roxb. }\end{array}$ & Kitah & Arecaceae & Roots & Laxative \\
\hline 15 & $\begin{array}{l}\text { Rauvolfia serpentina (L.) } \\
\text { Benth. Ex Kurz }\end{array}$ & God & Apocyanaceae & Roots & $\begin{array}{l}\text { Roots used to relieve } \\
\text { from nervous } \\
\text { disorders }\end{array}$ \\
\hline 16 & Smilax macrophylla Roxb & Atkir & Smilaceae & $\begin{array}{l}\text { Roots, } \\
\text { Stems }\end{array}$ & $\begin{array}{l}\text { Roots used for } \\
\text { urinary complaints; } \\
\text { stems used as tooth } \\
\text { brush }\end{array}$ \\
\hline 17 & $\begin{array}{l}\text { Woodfordia fruticosa (L.) } \\
\text { Kurz }\end{array}$ & Iche & Lythraceae & Flowers & $\begin{array}{l}\text { Dried flowers are } \\
\text { used as astringent }\end{array}$ \\
\hline 18 & $\begin{array}{l}\text { Xantolis tomentosa (Roxb.) } \\
\text { Rafin. }\end{array}$ & Dhumodhur & Sapotaceae & Fruits & $\begin{array}{l}\text { Fruits contain a } \\
\text { thermostable } \\
\text { anticholeric } \\
\text { principle }\end{array}$ \\
\hline
\end{tabular}

\section{OtherUses}

\section{Feed}

In spite of being a rich source of nutrition and easy availability in the rural areas these flowers are not very popular as food. Only a small quantity of flowers is consumed raw, cooked, or fried in different parts of India (The Wealth of India, 1962). Apart from food and liquor, the leaves and flowers of mahua are used as a source of cattle (basically cow, sheep and goat) feed. 


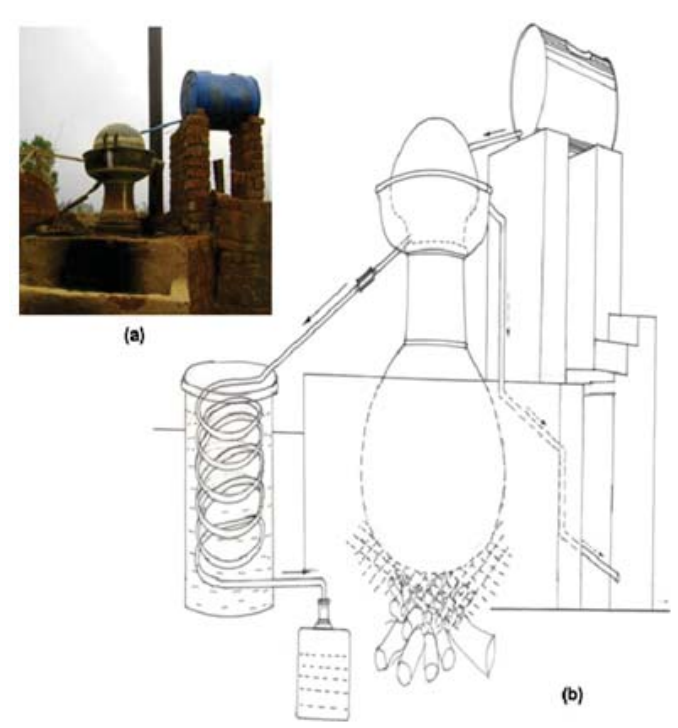

Figure 5. (a) Large scale traditional mahuli distillation plant

(b) Outer sketch of large scale distillation plant.

\section{Oil}

Oil is extracted from the mahua seeds (Fig. 1k) by using traditional oil extraction units (Fig. 11). Mahua seed oil is used as the vegetable oil for cooking purposes by the tribal people. Fresh oil is yellow in color while commercial oils are generally greenish yellow with a disagreeable odor and taste. The mahua seed cake (after extraction of oil) is used to control predatory fish present in the ponds and lakes. The presence of a poison saponin in the cake may be responsible to kill the predatory fish (Patel and Naik, 2010). Sidhu et al. (2009) reported aflatoxins produced by some toxigenic strains of Aspergillus. niger in the seed and its cake may be a cause to inhibit these predatory fish.

\section{Oil Cake}

Mahua oil cake is also used as cheap organic manure either alone or in mixture with ammonium sulphate. It was reported that the mahua seed cake contains 3.5\% nitrogen and $50.51 \%$ protein which may be a cause to use as organic manure (Patel and Naik, 2010).

\section{Medicine}

The Santhal peoples utilize different parts of the mahua tree for medicine purposes. Mahua oil has emolument properties and is used in skin diseases, rheumatism, and headache. Mahua seed paste is applied to cure muscle fatigue and relieve pain in the muscles and joints. The application also improves the texture and vigor of skin. Mahua seed oil is used as ointment to prevent crack in the skin in winter. The flower juice is used in the treatment of enlargement of auxiliary gland, necrotic disorder and taken with cow's milk to relieve from cough and bronchitis. 


\section{Bio-ethanol}

The recent studies have demonstrated that mahua flowers can serve as a renewable feed stock for commercial bio-ethanol production (Behera et al., 2010a, b). The ethanol yield varies from 1,45,000 to 1,55,000 litre/ton flowers, depending on the location, season, and genotype of mahua plants (Behera et al., 2010c).

\section{Mabua Influences Tribal Economy}

According to our study, the existing unhygienic collection and processing practices are the major factors affecting the food and beverage quality of mahua flowers. In spite of these measures, however, the poor tribes have not been able to reap the desired benefit from mahua as it continues to be regulated by Excise rules under the Bihar and Orissa Excise Act, 1915, which brands it an intoxicant and subjects it to all the duties, taxes, fees, and levies that are applicable in case of other intoxicants. As a result, the poor people and their collective enterprises are facing a lot of hardships and harassment since they are left with very little profit after paying all these taxes and duties. As this tree grows mainly in forest area and also in waste and fallow land, its cultivation would not hinder any impact on food production or cultivatable land. However, the major product i.e., bio-ethanol will play an important role in future sustainable energy supply which will affect the country's economy.

\section{CONCLUSION}

Mahua tree, as a whole, supplies food (flower), feed (leaf, flowers), timber (trunk), refreshing beverage (mahuli), bio- fuel [bio-ethanol (flower) and bio-diesel (seeds), and medicine (bark)] to the tribal population of Santhal community of Odisha. It is a secondary staple food which is consumed along with rice, ragi, jowar and sweet potato. Beside flowers, the seed oils are used as edible oil, seed cake (after extraction of oil) to control predatory fish in pond. Despite its multifarious uses, the people who have been preserving the tree species for centuries and depend on it for day to day livelihood do not reap the financial benefits they deserve. The traders and the middlemen take the major share of the financial gain out of the mahua business. Nevertheless, mahua plays a crucial role of this tribal's life in providing sustainable livelihood.

\section{ACKNOWLEDGEMENT}

First and foremost we thank the tribal people of Chandbill village for their enthusiasm and support and their constant good humor. We are also thankful to UGC [(Letter F. No. 32-573/2006(SR), dated 17.07.07], New Delhi for financial support to carry out this work.

\section{REFERENCES}

AWASTHI, Y.C., S.C. BHATNAGAR and C.R. MITRA. 1975. Chemurgy of sapotaceous plants: Madhuca species of India. Economic Bot. 29:380-389. 
BHAGMOL and V. JOSHI. 2002. Underutilized plant resources. http://www.Ipgri.Cgiar.org/publications.

BEHERA, S., S. KAR, R.C. MOHANTY and R.C. RAY. 2010a. Comparative study of bioethanol production from mahua (Madhuca latifolia L.) flowers by Saccharomyces cerevisiae cells immobilized in agar agar and $\mathrm{Ca}$-alginate matrices. Applied Energy 87(1):96-100.

BEHERA, S., R.C. MOHANTY and R.C. RAY. 2010b. Ethanol fermentation of mahua (Madhuca latifolia L.) flowers using free and immobilized bacteria Zymomonas mobilis MTCC 92. Biologia, sect.Cell. Mol.Biol. 65(3):416-421.

BEHERA, S., R.C. MOHANTY, and R.C. RAY. 2010c. Comparative study of bioethanol production from mahua (Madhuca latifolia L.) flowers by Saccharomyces cerevisiae and Zymomonas mobilis. Applied Energy 87:2352-2355.

BRAHMAM, M. and H.O. SAXENA. 1990. Ethnobotany of Gandha mardhan hills - some note worthy folk medicinal uses. Ethnobotany 2:71-77.

JOSHI, S.G. 2001. Medicinalplants. Oxford and IBH Publishing, New Delhi, India.

MISHRA, R.K., V.P. UPADHYAY, S. BAL, P.K. MOHAPATRA and R.C. MOHANTY. 2006. Phenology of species of moist deciduous forest sites of Similipal biosphere reserve. J. Ecol. Appl. 11:5-17.

PATEL, M. and S.N. NAIK. 2010. Flowers of Madhuca indica J.F. Gmel.: Present status and future perspectives. Ind. J. Nat. Products Res. 1(4): 438-443.

SHARMA, A.K. and A.K. BISWAL. 2010. Use of potential medicinal plants in the indigenous preparation of fermented food by santal tribes in Mayurbhanj, Orissa, India. Proceedings of the Symposium on Medicinal Plants of Similipal Reserve, Baripada, Souvenir, pp. 108-117.

SIDHU, O.P., H. CHANDRA and H.M. BEHL. 2009. Occurrence of aflatoxins in mahua (Madhuca indica Gmel.) seeds: Synergistic effect of plant extracts on inhibition of Aspergillus flavus growth and aflatoxin production. Food Chem. Toxicol. 47:774-777

SWAIN, M.R., S. KAR, A.K. SAHOO and R.C. RAY. 2007. Ethanol fermentation of mahua (Madhuca latifolia L.) flowers using free and immobilized yeast Saccharomyces cerevisiae. Microbiol. Res. 162(2):93-98.

THE WEALTH OF INDIA. 1962. A dictionary of Indian raw materials and industrial products. Publication and information directorate (CSIR), New Delhi, India, 6: 207-215. 